special needs of the studies and operations to be served, while in regard to the latter an information service which derives its life from its users either as contributors or as recipients is not a bureaucratic processing machine but a positive and creative element in national life.

These discussions were echoed in that following Mr. F. C. Francis' paper on September 19 on "The British Museum as a Special Library". Pointing out that the librarian cannot be content with cataloguing and classifying his stocks but must always be on the look-out for means to make his books known and to make them play their full part in the growth of know ledge, Mr. Francis explained how, broadly speaking, the British Museum has itself tended to specialize on subjects that might be roughly grouped as humanistic. It is the practice of the Museum to attempt to add to its collections 'English' books printed abroad, and also to buy books by outstanding writers, and really important books likely to be of historical importance in every field of knowledge. Scientific works published in the general proceedings of learned societies and academies, or in series, or as dissertations will, almost certainly, be found in the British Museum Library in complete ranges, as will the publications of foreign Governments, which aga in include works in all branches of study. Generally speaking, the collections are strong on the historical side of most subjects and weakest in modern foreign technical literature in non-humanistic subjects. Even here, Mr. Francis pointed out that of 112 items on pp. 226, 227 of the "World List of Scientific Periodicals", the British Museum has seventeen, the Natural History Museum Library five and the Science Library twenty-two, while of the seventeen, five are not to be found elsewhere. Similarly, out of 87 items on pp. 510-11, ten are in the Museum (and three only there), five in the Natural History Museum, and sixteen in the Science Library. Again, the Museum has no fewer than 111 items not included in the recent ASLIB List of Scientific and Technical Periodicals received from the U.S.S.R. during the period 1933-42. Finally, commenting on Mr. C. C. Barnard's suggestion, Mr. Francis urged that we should first carefully consider the place which each library, whether a national library or a special library, can take in a properly thought-out scheme devised to fulfil the tasks allotted to it as economically as possible. The organization of collecting so as to provide up-to-date, accurate and complete information on the subjects covered requires a measure of unified control if special libraries are not to be doing the same work, and he thought centralization rather than dispersal of our great reference library services should be the ideal.

At the following session, Major Irving J. Newman deseribed the organization of American Photographie Information Services in Great Britain and included a showing of the film "Report from the Aleutians". The afternoon session of the Conference on September 19 was devoted to a discussion on the co-ordination of abstracting, at which Prof. R. S. Hutton presided. Referring to the earlier ASLIB discussions and inquiry on this question initiated in 1931, and to Prof. J. C. Philip's paper "Efficiency with Economy in Abstracting", Prof. Hutton suggested that the discussion should centre on such points as whether existing abstracting services adequately cover the delegates' field of interest, and whether there is duplication in their particular fields. If they run their own abstracting service, is that because existing services do not cover the field, are too slow or cannot cater for their special needs? Again, can a centralized abstracting service adequately serve their special field of interests or secondary interests indirectly related to their main field of research? The discussion was opened by Dr. S. C. Bradford, who put the case for a central abstracting service with his usual ability. Mr. King gave a brief statement of the steps already taken in regard to collaboration in the preparation of scientific abstracts arising out of the report of the British Commonwealth Science Committee. Despite a full discussion, it cannot be said that any tangible result was achievèd. Most of thosé who participated appeared to be of the opinion that whatever centralized abstracting service may be organized, specialized abstracts will still be required to supplement it.

\section{SCIENTIFIC STUDY OF THE AMARYLLIDACE/E}

$\mathrm{T}$ HE American Amaryllis Society is again to be congratulated upon the publication of its ninth year-book "Herbertia" for 1942 (From the Society, Orlando, Florida, U.S.A. 3.25 dollars post paid). The Society, through its able editor Dr. Hamilton $P$. Traub, has brought together a large number of short contributions which deal with all aspects of the Amaryllidaceæ. Detailed descriptions of the Ixolirion tribe, with keys and descriptions of species, are given by Dr. Traub, and include chromosome data for I. tartaricum. The genus Crinum is also the subject of a comprehensive review by Dr. J. C. Th. Uphof. Suitable illustrations play a considerable part in the correct recognition of species, and Major Albert Pam of Broxbourne, England, has prepared an extensive check-list of coloured plates of amaryllids which have been published in the literature. A new species of Hemerocallis, $H$. altissima, is described by Dr. A. B. Stout, who also outlines the various stages in the breeding of a red-flowered day-lily. Starting with Hemerocallis flava, $H$, aurantiaca, $H$. Thunbergii and the Europa day-lily, hybridization and selective breeding produced the Theron class, with petals almost wholly red. Further breeding has made possible the introduction of bi-coloured flowers, and blooms with various geometrical arrangements of red upon a yellow ground.

Cytology of the genus Narcissus forms the subject of a paper by Dr. Abilio Fernandes of Coimbra, Portugal, who is a recipient of the Society's Herbert Medal. Chromosome numbers for fifty-seven species, varieties and forms, with information about the relat. ive sizes of various pairs, are combined with more general considerations. Diploids, for example, do not grow on acid soils ( $p H \quad 3 \cdot 7 \cdot 6 \cdot 2)$, whilst hypotetraploids $(2 n=26)$ can grow on soils of moderate acidity and on neutral and alkaline ones $(p \mathbf{H} 5 \cdot 7-7 \cdot 8)$. Cytological studies also reinforce the morphological subdivision of the genus into three groups. Some vitamins, hormones, pyrimidines and purines, with certain other substances, were found by Dr. F. T. Addicott to increase the percentage germination and tube-length of pollen grains of Milla sp. This fact should materially assist breeders to effect crosspollination between varieties otherwise difficult of fertilization.

Virus diseases are also considered in the year-book. Earl Hornback lists the species of Narcissus in order of resistance to such maladies, placing $N$. Tazetta as 
most resistant, with double forms, Poetaz and Poeticus varieties as most susceptible. L. S. Hannibal finds, however, that not many other genera of the Amaryllidacea are affected by mosaic diccases. Several factors in the propagation of alstroemerids are of scientific interest. Alstrocmer,a seeds, for example, must have sun before they will germinate, whereas seeds of Eomarea must $k \Leftrightarrow$ protected from the sun, according to Harry L. Stinson. L. S. Hannibal shows, among other factors, that in the further treatment of scedlings, alstroemerias must not suffer any crowding of the roots, otherwice flowers will not be produced. Vegetative propagation of Homerocallis by crown cuttings has keen further studied by V. T. Stoutemyer, who finds that the cuttings grow much faster and make greater weight if they are given six hours extra light each day, than in conditions of ordinary illumination.

Other aspects of practical culture, of harvesting, storage, forcing and of garden combination are dealt with in the volume.

It is difficult to escape the conclusion that knowledge of the horticultural science, genetics and taxonomy of the Amaryllidaceæ has advanced more than that of any other group during the last decade. Perhaps it is because "Herbertia" gathers together all the items into a connected whole, but there is also the specialist stimulus provided by a Society bent upon the encyclopadic study of a relatively small field which is replete with garden beauty, world-wide in origin and distrikution, and full of scientific interest.

\section{FORTHCOMING EVENTS}

(Meetings marked with an asterisk * are open to the public)

Friday, October 22-Saturday, October 23

Town and Country Puaning Association (at the Royal Empire Society, Northumberland Avenue, London, W.C.2).-Conference on
"Country Towns in a National Planning Policy"."

Friday, October 22-Sunday, October 24

INSTTTUTE OF INDUSTRIAL ADMTNTSTRATION (at the Waldorf Hotel, Aldwych, London, W.C.2).-Conference on "Management in Action".

\section{Saturday, October 23}

Sheftield Metalidratcal Assocjatjon, at 2.30 p.m.-Discussion on "The Education and Training of Metallurgists" (to be opcned by Dr. Edwin Gregory).

Monday, October 25

RoXal Geographical SocibTX (at Kensington Gore, London, S.W.7), at 5 p.m.- "Flying Boats over Africa" (Kodachrome Film by courtesy of B.O.A.O., Commentary by Mr. Ronald W. Waugh).

INSTITUTION OF ELECTRIOAL ENGINEFrs (at Savoy Place, Victoria Eimbarkment, London, W.C.2), at 5.30 p.m.-Discussion on "How Far is International Standardization in the National Interest "?" (to be opened by Colonel Sir A. Stanley Angwin).

Association of atgstrtak Fnglnegrs, Chemists and Solentifio WORKERS IN GREaT BRITATN (at the Austrian Centre Swiss Cottage, 69 Dton Avenue, Hampstead, London, N.W.3), at 7 p.m.-Mr. David Co Eton Avenue, Hampstead, London, N.W.3), at 7 p,m.-Mr. David Planning of a Water System in U.S.A.".

\section{Tuesday, October 26}

BRITISH SocteTY For INTERNational BtBLiography (at the Science Museum, Exhibition Road, South Kensington, London, S.W.7, at

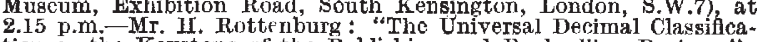
tion as the Keystone of the Publishing and Bookselling Business"; Dr. R. L, Sheppard: "The Bureau of Hygiene and Tropical Diseases". ChADWIOK PUBLIC LECTURe (at the London School of Hygiene and Tropical Medicine, Keppel Street, Gower Strcet, London, W.C.1), at 2.30 p.m.-Miss Margery Fry : "Ill Health and Iil Doing".*

EDGENICS SoorbTy (at the Royal Society, Burlington House, Piccadilly, London, W.1), at 5.30 p.m.--Dr. A. Spencer Paterson: "The

Thursday, October 28

OIL aNd Colotr Chemists' Association (Manchester Skotion). (in the Engineers' Club, Albert Square, Manchester), at 2 p.m.Dr. W. J. S. Naunton: "Molecules without Tears".

IINNEAN SOCIETY OF LONDON (joint meeting with the ZOOLOGICAX SOCIEYY OF LONDON) (at the Linnean Society, Burlington House, Piccadilly, London, W.1), at 3 p.m.-General Meeting ; at 3.15 p.m.
Dr. J. F. G. Wheeler: "On a Humpacked Whale taken in Bermuda in 1942"; ; 3.35 p.m.-Mr. Gilbert J. Arrow : "Polymorphism in Giant Rectlrs"; at, 3.55 p.m.-.-Dr. Y. J. Charman : "1939 Cambridgo

BRITISI TNSTITUTION OF RADIO ENGINEERS (IONDON SFCtion) (at the Institution of Structural Engineers, 11 Upper Belgrave Street London, s.W.1), at 6.30 p.m.-Mr. John Logie Baird: "Colour and tereoscopic Television".

Assoctation of AdSTRIan Engineers, Chemists and Solentifto WORKERS IN GREAT BRITAIN (joint meeting with the ROYAL NETHERLANDS INSTITUTION OF ENGINEERS) (at the Institution of Mcchanical Fingincers, Storey's Gate, St. James's Park, London, S.W.1), at Friday, October 29

NORTH-EAST COAST INSTTTUTION OF ENGINEERS AND SHIPBUITDERS (in the Lecture Theatre of the Mining Institute, Newcastle-uponAyne), at 6 p.m.-Dr. G. Applied to Engincering Practice" (Andrew Laing Lecture).

\section{Saturday, October 30}

RoYar ANTHRopological INSTITUTE (at the Royal Socisty, Burl ington House, Piccadilly, London, W.1 ).-Centenary Meeting.

At 11.15 a.m.-Sir John L. Myres: "A Century of Our Work".

At 3 p.m. (at 21 Bedford Square, Iondon, W.C.1). - The Future of Anthropology": (Dr. G. M. Morart: Physical Anthropology ; Dr. R. Firth: Social Anthropology).

\section{APPOINTMENTS VACANT}

APPICATIONS are invited for the following appointments on or before the dates mentioned:

EDUCATIONAI PSYCHOLOGIST-Ihe Director of Education, Municipal Buildings, Castle Strect, Aberdeen (Octobcr 30 ).

Teacher (Male) of Genkrat Scrence and Mathematics to students in full-time Junior and part-time day courses in the Collcge of Technology - The Director of Editcation, Education Offices, Rother-

HORTICULTURAL OFTICER to take charge of advisory and demonstration work on commercial holdings and matters arising frcm the Horticultural Cropping Orders-The Exccutive Officer, Hampshire War Agricult
(October 30).

WATFRWORKS ENGINEER AND MANAGER-The Town Clerk, Town Hall, Halifax (endorsed 'Waterworks Engineer and Manager') (November 1)

ASSISTANT LECTURER IN ZOOLOGY-The Registrar, University College, Nottingham (November 1).

ASSISTANT LECTURER IN AGRICULTURAL Bactertology-The Registrar, University, Leeds 2 (November 6).

Professor of Enginelinga-The Registrar, University College, Singleton Park, Swansea (November 20).

SENIOR LECTURER IN ELECTIOTECHNOLOGY at lcarling Technical College, Chile-The British Council, 3 Hanover Street, London, W.1 (endorsed 'Chile')

AsSISTANT ENGINERR for the Government of Northern Rhodesia Public Works Department-The Ministry of Labour and National Service, Central (Tcchnical and Scientific) Register, Alexandra House, Kingsway, London, W.C.2 (quoting Reference No. E.697).

WATERWORKS FingrNeER for the Nigerian Government Public Works Department-The Ministry of Labour and National Service, Central (Technical and Scientific) Register, Alexandra House, Kingsway, London, W.C.2 (quoting Reference No. E.771).

EXECDTIVD ENGINEER for the Sicrra Leone Government Public Works Department-The Ministry of Labour and National Srrvice, way, London, W.C.2 (quoting Reference No. E.774).

MASTER OF ENGINEERING, whose main work will be the teaching of Fngineering and the organization of Junior Technical Classes for boys of 14 to $16-$ The Hcadmaster, 'The Gatcway School, Leicester.

CIVILIAN TECHNICAL OFFICER for a Government Department near London with (1) expert knowledge of direct and alternating current generators, regulating gear and switehgear, rotary and static converters, internal combistion engines, primary and eccondary batteries, radio communication senders, receivers and station accessories, telephone and transmission apparatus, including hand sets, carrice tclephony and vole frequency telegraph equipment, tcleprinter and cablelaying plant, or (2) ability to assess modern designs of above equipment for maintenance spares-The Ministry of Labour and National Service, Appointments Department, Q.S. 24, Kingsway, London, W.C.2 (quoting Reference No. Q.16848).

FOR GOVERNMENT POSTS IN INDIA-INDUSTRIAT PlanNing OFFTokr (GENERAL), (Reference No. C.1911A), with sound mechanical training, and at least five ycars subsequent supervisory experience in reconnized mechanical workshop: DESIGN OFFTCRR (Reference No. C.1912A), first-class Mechanical Engineer with up-to-date experience in Design of light Mechanical Engineering Work; ASSISTANT INDUSTRIAI PLANNING OFFICER (Ammunition) (Reference No. C.1913A), with frst-class mechanical training and knowledge of Modern Methods of Production and specialized experience in Light Press Tool Work and Machinery Components for Air Bomb; AssTSTANT INDUSTRIAI PlanNing OFfiokr (Non-Ferrous) (Reference No. C.1914A), with at least flve years' experience in Production of Non-ferrous Metals and Alloys, and be familiar with Wire Drawing, Shect and Strip Rolling, and Sand Casting and Electrodepositing; A ASISTANT INDUSTRIAL PLAFNING. OFFICER (Tools) (Reference No. C.1915A), with good eXperience in Machine Shop Process Planning and Jig Design expericnce -The Ministry of Labour and National Service, Central (Technical and Scientifle) Register, Alexandra House, Kingsway, London, W.C.2 (quoting the appropriate Reference No.) 